\title{
Amphipod fauna of the sponges Halichondria panicea and Hymeniacidon perleve in Lough Hyne, Ireland
}

\author{
Mark J. Costello*, Alan A. Myers \\ Department of Zoology, University College, Cork, Ireland
}

\begin{abstract}
Sponges Halichondria panicea (Pallas) and Hymeniacidon perleve (Montagu) were collected over 12 mo from 2 sites in Lough Hyne (Ine), southwest Ireland. The associated amphipod fauna was identified and species comparisons were made between sponge species and sites. The number of species was similar in both sponges and at both sites, but considerably higher than that described from other places. Most species differed significantly in their relative abundance between sponges and sites. Two species, Leucothoe spinicarpa and Perrierella audouiniana, were inquilinous in both sponges, while the other 30 species were epifaunal. The relationship between the sponge and the inquiline amphipods may be parasitic, and that with the epifaunal amphipods mutualistic. Over $70 \%$ of the amphipod launa of both sponges at both sites was made up of Caprella acanthifera, Microdeutopus anomalus, Corophium bonnellii, and Lembos websteri. The dominant species differed between sponges and sites, but the level of dominance and species rank abundance was similar in both sponges and at both sites. The relationship between dominance and species richness, as descriptors of assemblage structure, is discussed.
\end{abstract}

\section{INTRODUCTION}

Amphipod Crustacea are known to be an important component of the fauna associated with the sponges Halichondria panicea (Pallas) and Hymeniacidon perleve (Montagu) (Long 1968, Frith 1976, Peattie \& Hoare 1981). In North Hayling, southern England, amphipods constituted $30.5 \%$ of the species recorded on $H$. panicea and $29.0 \%$ on $H$. perleve (Frith 1976), and in the Menai Straits, northwest Wales, $37.0 \%$ on $H$. panicea (Peattie \& Hoare 1981). In Lough Hyne (formerly Ine), the sponges $H$. panicea and $H$. perleve were collected from 2 sites. The associated amphipod fauna was examined in terms of species composition, number (richness), dominance, rank and relative abundance, for each species and each site.

\section{STUDY AREA AND METHODS}

Lough Hyne is a sheltered marine inlet, $1 \times 0.75 \mathrm{~km}$ in size, on the southwest coast of Ireland. Its ecology

\footnotetext{
- Present address: Marine Biological Association, The Laboratory, Citadel Hill, Plymouth PL1 2PB, England
}

has been the subject of numerous studies, reviewed by Kitching \& Ebling (1967) and documented by Wilson (1984). Sea temperatures range from 8 to $18^{\circ} \mathrm{C}$ (Costello 1987 ), salinity 34.3 to $34.9 \%$, and the tidal range is 0.7 to $1.0 \mathrm{~m}$ (Kitching \& Ebling 1967). The lough is divided into North and South Basins by Labhra Island and Castle Island. The sublittoral has been divided into 6 major zones by Kitching et al. (1976).

Two sites were regularly sampled in this study; Curlew Bay which lies on the north side of Labhra Is., and the south shore of the South Basin between Codium Bay and Glannafeen Quay. Curlew Bay is part of the 'shallow-inshore' zone (Zone I of Kitching et al. 1976). It slopes gently from a beach which forms the isthmus between Labhra Is. and Castle Is. to about $4 \mathrm{~m}$ depth. The seabed is a silted shell gravel, with tufts of a filamentous red alga (Polysiphonia sp.). The most notable animals are the sea urchin Paracentrotus lividus Lamarck which occurs about the low tide mark, a bed of variegated scallops Chlamys varia $L$., and an abundance of the sponges Halichondria panicea, Hymeniacidon perleve, and Suberites domuncula (Olivi).

The South Shore of the lough is part of Zone II, a steep sloping 'rock-boulder' facies with soft mud 
between the boulders. Various algae, notably Cystoseira and an ephemeral Mesogloia sp., some tunicates (mostly Ascidiella aspersa O. F. Müller), the anemone Anemonia sulcata (Pennant), and the sponges Halichondrea panicea, Hymeniacidon perleve and Suberites domuncula occur on the rocks and boulders. However, colonies of $H$. perleve were generally smaller and less frequent than in Curlew Bay. $S$. domuncula was not further sampled after a preliminary investigation showed it to be without a macrobiota

Sponges of about $15 \mathrm{~cm}$ diameter were collected by SCUBA or snorkel diving, and sealed in plastic bags. On return to the laboratory (within 4 h of collection) the samples were stored at $4{ }^{\circ} \mathrm{C}$. Confinement in the bags resulted in the amphipods leaving their tubes and crevices in the sponge, which facilitated sorting. Amphipods were removed by gently washing the sponge over a $1 \mathrm{~mm}$ sieve. The sponge was then carefully examined for any remaining epifauna, and teased apart to find infauna. Samples were fixed and preserved in $70 \%$ ethanol. The remaining sponge tissue was dried at $60^{\circ} \mathrm{C}$ to constant weight.

Species were identified using techniques described by Chevreux \& Fage (1925), Lincoln (1979), Myers \& Costello (1984), and Myers \& McGrath (1984). Nomenclature follows Costello et al. (in press). It should be noted that Ampithoe helleri Karaman 1975 is considered to be a senior synonym of $A$. neglecta Lincoln 1976.

The proportional abundance of an amphipod species between the sponge species and sites was compared using a Z-test, such that $Z=\sqrt{Q}$, and

$$
\mathrm{Q}=\frac{\left(\mathrm{n}_{1} / \mathrm{N}_{1}-\mathrm{n}_{2} / \mathrm{N}_{2}\right)^{2}}{\left[\frac{\mathrm{n}_{1}+\mathrm{n}_{2}}{\mathrm{~N}_{1}+\mathrm{N}_{2}}\right]\left[1-\frac{n_{1}+\mathrm{n}_{2}}{\mathrm{~N}_{1}+\mathrm{N}_{2}}\right]\left[\frac{1}{\mathrm{~N}_{1}}+\frac{1}{\mathrm{~N}_{2}}\right]}
$$

where $\mathrm{n}_{1}, \mathrm{n}_{2}=$ number of amphipods of species $\mathrm{n}$ in sponges (or sites) 1 and 2 respectively; $N_{1}, N_{2}=$ total number of amphipods from sponges (or sites) 1 and 2 respectively. Values of $Z<1.96$ are not significant; if $Z$ $\geqslant 1.96$ then $p \leqslant 0.05$, if $Z \geqslant 2.57$ then $p \leqslant 0.01$, if $Z \geqslant$ 3.89 then $p \leqslant 0.001$

The level of dominance is the proportion that the most abundant (or 'dominant') species constitutes of the entire sample. The Pearson product-moment correlation coefficient was used to compare trends in species richness (= number of species), dominance and abundance (Bailey 1981). Species were ranked according to their abundance, and by assigning each species a number which remained constant (but the species position in the ranked species list changed) for each sponge and site, these ranks were similarly correlated.

\section{RESULTS}

\section{Distribution}

From 98 sponges sampled, almost 28000 adult amphipods of 32 species were collected (Table 1). While 58 specimens of Halichondria panicea were examined, compared with 40 Hymeniacidon perleve, the species composition of each sponge was very similar at each site. Although far more amphipods were collected from $H$. panicea, species richness was similar: 27 in the case of $H$. perleve from both sites and $H$. panicea from South Shore, and 25 in $H$. panicea from Curlew Bay.

Adult amphipods of all species, except some Stenothoe monoculoides, Dexamine thea, Gitana sarsi, Microprotopus maculatus, Metaphoxus fultoni and Harpinia crenulata, were retained by a $1 \mathrm{~mm}$ sieve. Numbers of individuals quoted therefore do not include juveniles, and numbers of the 6 above-mentioned small species have been underestimated.

Caprella acanthifera, Microdeutopus anomalus, Corophium bonnellii and Lembos websteri were the 4 most abundant species on both sponges, together constituting $71.0 \%$ of the amphipods on Halichondria panicea and $73.3 \%$ on Hymeniacidon perleve. The level of dominance was lower on $H$. panicea (22.7 vs $30.8 \%$ ) and on samples from South Shore (22.7 vs $29.0 \%$ ), than on $H$. perleve and Curlew Bay respectively (Table 1). At both sites, $M$. anomalus was the dominant species on $H$. perleve, and ranked second in abundance on $H$. panicea. However, on $H$. panicea from Curlew Bay $C$. acanthifera was dominant, while on H. panicea from South Shore L. websteri was dominant. Correlation coefficients between each sponge and site are shown in Table 2. Species ranks between each sponge and site are significantly positively correlated $(p<0.001)$. The coefficients do not show any greater similarity between sponges or between sites.

The proportion of all amphipods that each species constituted from a sponge or site is given in Table 1. The significance of changes in this proportion between sponge species and sites was examined using the Ztest (see Table 1 for values and levels of significance). It is apparent that most species differ markedly in the proportion that they contribute to the amphipod fauna from the different sponge species and sites.

Several species had a significantly greater relative abundance at a particular site on both sponge species, and on a particular sponge at both sites (Table 3). However, Corophium bonnellii was equally abundant on both Halichondrea panicea and Hymeniacidon perleve in Curlew Bay, but more abundant on the latter sponge on South Shore. Aora spinicornis was equally abundant at each site but in Curlew Bay it was more 
Table 1. Numbers of each amphipod species collected from each sponge species at each site ( $N$ ); percentage that $N$ is of the total number of amphipods for that column $(\%)$. Differences in amphipod numbers between sponge species and sites are compared as Z-test values, with level of significance of these shown

\begin{tabular}{|c|c|c|c|c|c|c|c|c|c|c|c|c|}
\hline \multirow[t]{2}{*}{ Species } & & \multicolumn{3}{|c|}{ Hymeniacidon perleve } & \multicolumn{3}{|c|}{ Halichondna pancea } & \multirow[t]{2}{*}{ Total } & \multicolumn{2}{|c|}{ Z: botween sites } & \multicolumn{2}{|c|}{$Z$ : between sponges } \\
\hline & & $\begin{array}{c}\text { Curlew } \\
\text { Bay }\end{array}$ & $\begin{array}{l}\text { South } \\
\text { Shore }\end{array}$ & Total & $\begin{array}{c}\text { Curlew } \\
\text { Bay }\end{array}$ & $\begin{array}{l}\text { South } \\
\text { Shore }\end{array}$ & Total & & $\begin{array}{c}H . \\
\text { perleve }\end{array}$ & $\begin{array}{c}H . \\
\text { panicea }\end{array}$ & $\begin{array}{c}\text { Curlew } \\
\text { Bay }\end{array}$ & $\begin{array}{l}\text { South } \\
\text { Shore }\end{array}$ \\
\hline No. of samples & & 22 & 18 & 40 & 26 & 32 & 58 & 98 & 40 & 58 & 48 & 50 \\
\hline Caprella acanthifera & $\mathrm{N}$ & 796 & 255 & 1051 & 3577 & 1303 & 4880 & 5931 & 5.89 & 25.72 & 21.65 & 6.29 \\
\hline Leach $181 \mathrm{~A}$ & $\%$ & 15.1 & 10.2 & 13.5 & 30.8 & 15.2 & 24.2 & 21.2 & $\cdots$ & & $\cdots$ & \\
\hline Microdeutopus anomalus & $\mathrm{N}$ & 1714 & 725 & 2439 & 2084 & 1094 & 3178 & 5617 & 3.09 & 10.09 & 20.93 & 19.33 \\
\hline (Rathke 1843) & $\%$ & 32.5 & 29.0 & 31.4 & 18.0 & 12.7 & 15.7 & 20.1 & & & & \\
\hline Corophium bonnellii & $\mathrm{N}$ & 803 & 722 & 1525 & 1737 & 1622 & 3359 & 4884 & 14.17 & 7.37 & 0.41 & 10.78 \\
\hline (Milne-Edwards 1830) & $\%$ & 15.2 & 28.9 & 19.6 & 15.0 & 18.9 & 16.6 & 17.5 & $\cdots$ & $\cdots$ & ns & \\
\hline Lembos websteri & $\mathrm{N}$ & 378 & 312 & 690 & 963 & 1950 & 2913 & 3603 & 7.70 & 28.78 & 2.54 & 11.16 \\
\hline Bate 1856 & $\%$ & 7.2 & 12.5 & 8.9 & 8.3 & 22.7 & 14.4 & 12.9 & $\cdots$ & $\cdots$ & & \\
\hline Ericthonius punctatus & $\mathrm{N}$ & 14 & 15 & 29 & 543 & 760 & 1303 & 1332 & 2.26 & 11.91 & 14.89 & 14.23 \\
\hline (Bate 1857) & $\%$ & 0.3 & 0.6 & 0.4 & 4.7 & 8.8 & 6.5 & 4.8 & & & $\cdots$ & $\cdots$ \\
\hline Stenothoe monoculoides & $\mathrm{N}$ & 231 & 139 & 370 & 588 & 200 & 788 & 1158 & 2.29 & 9.95 & 1.94 & 8.26 \\
\hline Montagu 1815 & $\%$ & 4.4 & 5.6 & 4.8 & 5.1 & 2.3 & 3.9 & 4.1 & & & ns & \\
\hline Microdeutopus versiculatus & $N$ & 498 & 60 & 558 & 473 & 92 & 565 & 1123 & 11.23 & 12.81 & 13.86 & 5.03 \\
\hline (Bate 1856) & $\%$ & 9.4 & 2.4 & 7.2 & 4.1 & 1.1 & 2.8 & 4.0 & $\cdots$ & $\cdots$ & $\cdots$ & $\cdots$ \\
\hline Gammarella fucicola & $\mathrm{N}$ & 282 & 20 & 302 & 374 & 54 & 428 & 730 & 9.69 & 12.66 & 6.60 & 0.93 \\
\hline (Leach 1814) & $\%$ & 5.3 & 0.8 & 3.9 & 3.2 & 0.6 & 2.1 & 2.6 & $\cdots$ & $\cdots$ & $\cdots$ & ns \\
\hline Lysianassa ceratina & $\mathrm{N}$ & 46 & 12 & 58 & 238 & 371 & 609 & 667 & 1.88 & 9.31 & 5.52 & 9.25 \\
\hline (Walker 1889) & $\%$ & 0.9 & 0.5 & 0.8 & 2.1 & 4.3 & 3.0 & 2.4 & ns & $\cdots$ & $\cdots$ & .. \\
\hline Dexamine thea & $\mathrm{N}$ & 196 & 86 & 282 & 201 & 54 & 255 & 537 & 0.60 & 6.95 & 7.87 & 11.08 \\
\hline Boeck 1861 & $\%$ & 3.7 & 3.4 & 3.6 & 1.7 & 0.6 & 1.3 & 1.9 & ns & $\cdots$ & $\cdots$ & $\cdots$ \\
\hline Leucothoe spinicarpa & $\mathrm{N}$ & 24 & 0 & 24 & 242 & 92 & 334 & 358 & 3.38 & 5.59 & 7.89 & 5.20 \\
\hline (Abildgaard 1789) & $\%$ & 0.5 & 0 & 0.3 & 2.1 & 1.1 & 1.7 & 1.3 & $\cdots$ & $\cdots$ & $\cdots$ & $\cdots$ \\
\hline Corophium sextonae & $\mathrm{N}$ & 5 & 13 & 18 & 9 & 334 & 343 & 361 & 3.65 & 20.71 & 0.36 & 8.51 \\
\hline Crawford 1937 & $\%$ & 0.1 & 0.5 & 0.2 & 0.1 & 3.9 & 1.7 & 1.3 & $\cdots$ & ... & ns & $\cdots$ \\
\hline Aora gracilis & $\mathrm{N}$ & 7 & 39 & 46 & 98 & 199 & 297 & 343 & 7.67 & 8.59 & 5.46 & 2.30 \\
\hline (Bate 1855) & $\%$ & 0.1 & 1.6 & 0.6 & 0.9 & 2.3 & 1.5 & 1.2 & $\cdots$ & $\cdots$ & $\cdots$ & • \\
\hline Aora spinicornis & $\mathrm{N}$ & 40 & 27 & 67 & 148 & 118 & 266 & 333 & 1.44 & 0.60 & 2.97 & 1.14 \\
\hline Afonso 1976 & $\%$ & 0.8 & 1.1 & 0.9 & 1.3 & 1.4 & 1.3 & 1.2 & ns & ns & $\cdots$ & ns \\
\hline Ampithoe rubricata & $\mathrm{N}$ & 9 & 10 & 19 & 83 & 147 & 230 & 249 & 1.91 & 6.59 & 4.46 & 4.88 \\
\hline (Montagu 1808) & $\%$ & 0.2 & 0.4 & 0.2 & 0.7 & 1.7 & 1.1 & 0.9 & ns & $\cdots$ & $\cdots$ & $\cdots$ \\
\hline Abludomelita obtusata & $\mathrm{N}$ & 55 & 21 & 76 & 75 & 43 & 118 & 194 & 0.85 & 1.35 & 2.73 & 1.97 \\
\hline (Montagu 1813) & $\%$ & 1.0 & 0.8 & 1.0 & 0.7 & 0.5 & 0.6 & 0.7 & ns & ns & ․ & \\
\hline Metaphoxus fultoni & $\mathrm{N}$ & 89 & 5 & 94 & 36 & 8 & 44 & 138 & 5.60 & 3.27 & 9.67 & 1.38 \\
\hline$(S \operatorname{sott} 1890)$ & $\%$ & 1.7 & 0.2 & 1.2 & 0.3 & 0.1 & 0.2 & 0.5 & $\cdots$ & $\cdots$ & $\cdots$ & ns \\
\hline Dexamine spinosa & $\mathrm{N}$ & 12 & 10 & 22 & 54 & 55 & 109 & 131 & 1.34 & 1.67 & 2.30 & 1.39 \\
\hline (Montagu 1813) & $\%$ & 0.2 & 0.4 & 0.3 & 0.5 & 0.6 & 0.5 & 0.5 & ns & ns & & ns \\
\hline Perrierella audouiniana & N & 33 & 4 & 37 & 30 & 37 & 67 & 104 & 2.79 & 2.10 & 3.62 & 1.96 \\
\hline (Bate 1857) & $\%$ & 0.6 & 0.2 & 0.5 & 0.3 & 0.4 & 0.3 & 0.4 & $\cdots$ & & $\cdots$ & \\
\hline Ampithoe ramondi & $\mathrm{N}$ & 0 & 0 & 0 & 0 & 36 & 36 & 36 & - & 6.98 & - & 3.24 \\
\hline Audouin 1826 & $\%$ & 0 & 0 & 0 & 0 & 0.4 & 0.2 & 0.1 & - & $\cdots$ & - & . \\
\hline Ampithoe helleri & $\mathrm{N}$ & 7 & 2 & 9 & 17 & 0 & 17 & 26 & 0.63 & 3.55 & 0.22 & 2.62 \\
\hline Karaman 1975 & $\%$ & 0.1 & 0.1 & 0.1 & 0.2 & 0 & 0.1 & 0.1 & ns & & ns & \\
\hline Gitana sarsi & $\mathrm{N}$ & 6 & 2 & 8 & 6 & 15 & 21 & 29 & 0.43 & 2.68 & 1.40 & 1.06 \\
\hline Boeck 1871 & $\%$ & 0.1 & 0.1 & 0.1 & 0.1 & 0.2 & 0.1 & 0.1 & ns & . & ns & ns \\
\hline Phtisica marina & $\mathrm{N}$ & 10 & 5 & 15 & 9 & 2 & 11 & 26 & 0.99 & 1.64 & 2.01 & 3.10 \\
\hline Slabber 1769 & $\%$ & 0.2 & 0.2 & 0.2 & 0.1 & 0.0 & 0.1 & 0.1 & ns & ns & & .. \\
\hline Ampithoe ganumaroides & $\mathrm{N}$ & 10 & 3 & 13 & 4 & 0 & 4 & 17 & 0.70 & 1.72 & 3.24 & 3.21 \\
\hline (Bate 1856) & $\%$ & 0.2 & 0.1 & 0.2 & 0.0 & 0 & 0.0 & 0.1 & ns & ns & & \\
\hline Microprotopus maculatus & $\mathrm{N}$ & 3 & 3 & 6 & 6 & 4 & 10 & 16 & 0.94 & 0.16 & 0.13 & 1.29 \\
\hline Norman 1867 & $\%$ & 0.1 & 0.1 & 0.1 & 0.1 & 0.1 & 0.1 & 0.1 & ns & ns & ns & ns \\
\hline Cheirocratus sundevalli & $N$ & 5 & 0 & 5 & 8 & 1 & 9 & 14 & 1.54 & 1.91 & 0.56 & 0.54 \\
\hline (Rathke 1843) & $\%$ & 0.1 & 0 & 0.1 & 0.1 & 0.0 & 0.1 & 0.1 & ns & ns & ns & ns \\
\hline Harpinia crenulata & $\mathrm{N}$ & 4 & 6 & 10 & 0 & 1 & 1 & 11 & 1.89 & 1.16 & 2.97 & 4.00 \\
\hline (Boeck 1871) & $\%$ & 0.1 & 0.2 & 0.1 & 0 & 0.0 & 0.0 & 0.0 & ns & ns & .. & $\cdots$ \\
\hline Penoculodes longimanus & $\mathrm{N}$ & 0 & 2 & 2 & 0 & 1 & 1 & 3 & 2.06 & 1.16 & - & 1.83 \\
\hline (Bate \& Westwood 1868) & $\%$ & 0 & 0.1 & 0.0 & 0 & 0.0 & 0.0 & 0.0 & & ns & - & ns \\
\hline Apherusa bispinosa & $\mathrm{N}$ & 0 & 2 & 2 & 0 & 0 & 0 & 2 & 2.06 & - & - & 2.62 \\
\hline (Bate 1856) & $\%$ & 0 & 0.1 & 0.0 & 0 & 0 & 0 & 0.0 & & - & - & . \\
\hline Ceradocus semiserratus & $\mathrm{N}$ & 2 & 0 & 2 & 0 & 0 & 0 & 2 & 0.97 & - & 2.10 & - \\
\hline (Bate 1862) & $\%$ & 0.0 & 0 & 0.0 & 0 & 0 & 0 & 0.0 & ns & - & . & - \\
\hline Jassa falcata & $\mathrm{N}$ & 0 & 1 & 1 & 0 & 0 & 0 & 1 & 1.45 & - & - & 1.85 \\
\hline (Montagu 1808) & $\%$ & 0 & 0.0 & 0.0 & 0 & 0 & 0 & 0.0 & ns & - & - & ns \\
\hline Sunamphtoe pelagica & $\mathrm{N}$ & 0 & 0 & 0 & 0 & 1 & 1 & 1 & - & 1.16 & - & 0.54 \\
\hline (Milne-Edwards 1830) & $\%$ & 0 & 0 & 0 & 0 & 0.0 & 0.0 & 0.0 & - & ns & - & ns \\
\hline Total & & 5279 & 2501 & 7780 & 11603 & 8594 & 20197 & 27977 & & & & \\
\hline No. of species & & 27 & 27 & 30 & 25 & 27 & 29 & 32 & & & & \\
\hline
\end{tabular}


Table 2. Correlation coefficients between the rank abundance of species from the sponge species and sites. All values are significant at $p \leqslant 0.001$

\begin{tabular}{|c|c|c|c|}
\hline & $\begin{array}{l}\text { Hymeniac } \\
\text { Curlew } \\
\text { Bay }\end{array}$ & $\begin{array}{l}\text { inperleve } \\
\text { South } \\
\text { Shore }\end{array}$ & $\begin{array}{c}\text { Halichondria panicea } \\
\text { Curlew } \\
\text { Bay }\end{array}$ \\
\hline H. perleve & & & \\
\hline $\begin{array}{l}\text { Curlew Bay } \\
\text { H. panicea }\end{array}$ & 0.884 & & \\
\hline $\begin{array}{l}\text { Curlew Bay } \\
\text { H. panicea }\end{array}$ & 0.936 & 0.887 & \\
\hline South Shore & 0.812 & 0.872 & 0.917 \\
\hline
\end{tabular}

Table 3. Groups of amphipod species which occurred in significantly greater relative abundance at one site for both sponge species, or on one species of sponge at both sites. Detailed statistics are given in Table 1

\begin{tabular}{|ll}
\hline Curlew Bay & South Shore \\
Caprella acanthifera & Corophium bonnellü \\
Microdeutopus anomalus & Lembos webster \\
Microdeutopus versiculatus & Ericthonius punctatus \\
Gammarella fucicola & Corophium sextonae \\
Leucothoe spinicarpa & Aora gracilis \\
Metaphoxus fultoni & \\
Perrierella audouiniana & \\
Hymeniacidon perleve & Halichondria panicea \\
Microdeutopus anomalus & Caprella acanthifera \\
Microdeutopus versiculatus & Lembos websteri \\
Dexamine thea & Ericthonius punctatus \\
Abludomelita obtusata & Lysianassa ceratina \\
Phtisica marina & Leucothoe spinicarpa \\
Ampithoe gammaroides & Ampithoe rubricata \\
Harpinia crenulata &
\end{tabular}

abundant on $H$. perleve. Although Stenothoe monoculoides and Ampithoe helleri were more abundant on $H$. perleve on South Shore, they were more abundant on $H$. panicea in Curlew Bay. Thus 19 species were conservative in their distribution on a sponge or site (Table 3), but in 2 species the 'favoured' sponge changed between sites. Lastly, the absence of Leucothoe spinicarpa from $H$. perleve on South Shore, and presence of Ampithoe ramondi only on H. panicea and only on South Shore, is notable.

Only 2 species, Leucothoe spinicarpa and Perrierella audouiniana, were found to occur inside the sponge (inquilinous). They were often found lying adjacent to the main inhalent canals. All other amphipods either lived in crevices on, built their tubes on, or were associated with algae and tunicates on the outer surface of the sponge. Male, ovigerous and non-ovigerous female, and juvenile $L$ spinicarpa were found inside sponges. Most $P$. audouiniana collected were adult sized but were not sexed. However, 2 ovigerous fema- les and 4 juveniles were among the 109 specimens collected in the sponges.

\section{Richness, dominance and abundance}

The degree of correlation between sponge size and species richness, dominance and abundance, was assessed for each sponge species (Table 4). Sponge size was indicated from dry weight measurements, which ranged from 1.93 to $76.05 \mathrm{~g}$ for Halichondria panicea and 3.68 to $59.04 \mathrm{~g}$ for Hymeniacidon perleve. With increasing sponge size, amphipod abundance increased significantly and dominance decreased sig-

Table 4. Correlation coefficients between sponge dry weight amphipod species richness, dominance and abundance. Upper values are for Halichondria panicea, lower for Hymeniacidon perleve

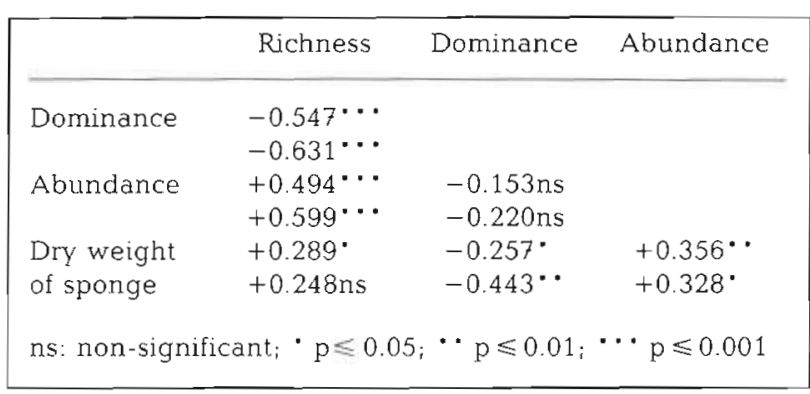

nificantly for both $H$. panicea and $H$. perleve. In addition, species richness was significantly positively correlated with size of $H$. panicea but not with $H$. perleve. There was no significant correlation between amphipod abundance and dominance. Species richness was negatively correlated with dominance and positively correlated with abundance for both sponges; both correlations were highly significant (Table 4).

\section{DISCUSSION}

\section{Faunal associations}

The amphipod fauna of the sponges Halichondria panicea and Hymeniacidon perleve may be divided into 2 groups: species that are inquiline, and species that inhabit the outer surface of the sponge. The former were represented by Leucothoe spinicarpa and Perrierella audouiniana in Curlew Bay and on South Shore. According to Ortiz (1975), L. spinicarpa can spend its entire life cycle inside its host. Preliminary observations presented here suggest that the same is true of $P$. audouiniana.

Barnard (1974) describes the 'inquilinous habit' as 
'parasitic sucking', while other definitions of inquilinism state that the inquiline does not harm its host (Lincoln et al. 1982). However, descriptions of the tissue reaction of the sponge Tethya lyncurium Lamarck to Leucothoe spinicarpa (Connes 1967), and of the sponge Suberities carnosus typicus (Johnston) to Perrierella audouiniana (Connes et al. 1971), indicate that the sponge forms a protective envelope around the amphipod. $P$. audouiniana apparently remains in this 'gall' and suspension-feeds from the water flowing through the sponge (Connes et al. 1971). In the present study, both inquilinous species were associated with the inhalent canals of the host sponge, where they would presumbably be in the best position to suspension-feed. $L$. spinicarpa is also a frequent inquiline of ascidians (e.g. Tattersall 1913, Gotto 1959, Ryland \& Nelson-Smith 1975), and it seems likely that it also suspension-feeds from the host's water current. These inquiline amphipods appear to be parasitic, because although not feeding directly on the host, they do feed on material which the host may have assimilated.

Vader (1984) considers that amphipod associations with sponges are recent in origin due to the apparent absence of any distinctive morphological features related to their inquiline life-style. However, amphipods may not find distinctive adaptations necessary for the inquiline habit. Adaptations for suspension-feeding are likely to be similar for inquiline and free-living amphipods.

Other inquiline amphipods also occur in Lough Hyne. In areas of strong water movement, such as the Rapids and near open coast here, Colomastix pusilla and Tritaeta gibbosa are sponge inquilines (Costello 1987). The former sits in the sponge oscula (Peattie \& Hoare 1981) and the latter excavates a burrow in the sponge surface (Fage 1928).

Epifaunal sponge associates may keep the sponge surface free of detritus by their feeding and tubebuilding actions. In return, the sponge provides a suitable surface which is perennial and physically stable. Hence, this association may be mutualistic. Frith (1977), in laboratory experiments, found that $\mathrm{Mi}$ crodeutopus anomalus and Corophium sextonae chose Halichondria panicea and Hymeniacidon perleve, rather than dried sponge or seaweed.

\section{Species richness}

The amphipod fauna of Halichondria panicea and Hymeniacidon perleve in Lough Hyne appears to be richer in amphipod species than that found on the same, or other, sponge species at other places (Table 5). A study in a South Carolina (USA) saltmarsh recorded 13,13,14, and 18 amphipod species (total of
Table 5. Number of amphipod species and samples taken from the sponges Halichondria panicea and (in parentheses) Hymeniacidon perleve, in this and other studies

\begin{tabular}{|c|c|c|c|c|c|}
\hline \multirow{2}{*}{ ( } & \multirow{2}{*}{$\begin{array}{c}\text { North } \\
\text { Haylingl } \\
\text { (S. England) }\end{array}$} & \multirow{2}{*}{$\begin{array}{c}\text { Menai } \\
\text { Straits }^{2} \\
\text { (N. Wales) }\end{array}$} & \multicolumn{3}{|c|}{ Lough Hyne ${ }^{3}$} \\
\hline & & & $\begin{array}{c}\text { Curlew } \\
\text { Bay }\end{array}$ & $\begin{array}{l}\text { South } \\
\text { Shore }\end{array}$ & Total \\
\hline $\begin{array}{l}\text { No. of } \\
\text { species }\end{array}$ & $11(9)$ & 16 & $25(27)$ & $27(27)$ & $29(30)$ \\
\hline $\begin{array}{l}\text { No. of } \\
\text { samples }\end{array}$ & $116(60)$ & 29 & $26(22)$ & $32(18)$ & $58(40)$ \\
\hline${ }^{1}$ Frith 19 & $976 ;^{2}$ Peatti & Hoare 1 & ${ }^{3}$ prese & ent study & \\
\hline
\end{tabular}

$21 \mathrm{spp}$.) on 4 sponge species respectively (Biernbaum 1981). Thus 9 to 18 amphipod species have been found associated with sponges in other study areas, compared to 25 to 27 species in Lough Hyne.

The amphipods of Lough Hyne have been particularly well studied, and 103 species have been recorded in the area to date (Costello 1987). This richness reflects not only the attention of biologists but the wide range of aquatic habitats in Lough Hyne (Renouf 1931, Kitching \& Ebling 1967). From each habitat locus, individuals may spread to less favourable habitats. For example, Jassa falcata is most abundant in the Rapids but was found only in low numbers on the sponges on the South Shore (Table 1). The richness of the amphipod fauna of sponges may therefore be a reflection of the rich habitat mosaic in this small sea lough.

\section{Assemblage structure}

The same 4 amphipod species ranked highest on both Halichondria panicea and Hymeniacidon perleve in Lough Hyne. In North Hayling. Frith (1976) found that 3 species ranked highest on these same sponges and on Mycale macilenta. Although Biernbaum (1981) found greater differences in dominance and rank of amphipods between 4 sponge species in a saltmarsh, a group of 7 species between them constituted the 4 top ranking amphipods on each sponge. The 4 highest ranking species in the Menai Straits (Peattie \& Hoare 1981), i.e. Caprella linearis, Tritaeta gibbosa, Colomastix pusilla, and Jassa falcata, are characteristic of areas of strong water movement and have been recorded from the tidal Rapids and open coast at Lough Hyne (Costello 1987). It would thus appear that geographical location and habitat type are more important than sponge species in determining the constitution of the amphipod assemblage.

Observations during the present study suggest that 
the sponges collected were at least 1 yr old when sampled. A study of the colonization of artificial substrate in Lough Hyne found a stable epifaunal amphipod assemblage to develop in 4 mo (Costello 1987). It is therefore likely that the amphipods on the sponges in the present study formed a stable faunal assemblage.

The amphipod fauna of Halichondria panicea and Hymeniacidon perleve at both sites in Lough Hyne was similar in species richness, composition, dominance and rank. However, there were statistically significant differences in the relative abundance of most species between sponges and sites (Table 1). In view of the paucity of data on the ecology of most of these species, the biological significance of these differences is obscure. The rate of water flow is greater at the South Shore site (Kitching \& Ebling 1971) and differences in water flow may affect the quality and quantity of suspended matter and rate of accumulation of detritus. Although sponge morphology was generally similar at both sites, $H$. perleve were smaller and less frequent on South Shore. In laboratory experiments, Nagle (1968) noted a competitive superiority of a species identified as Microdeutopus damnoniensis (Bate) (a doubtful identification in view of the known distribution of this species) over Corophium acutum Chevreux in slack water, and the reverse in fast-flowing water. He interpreted this to explain spatial distribution in the field. Interactions between amphipods and other faunal elements may also be involved. In the present work, it is notable that whereas 19 species were conservative in their preference of sponge or site (Table 3), Stenothoe monoculoides and Ampithoe helleri preferred different sponges at different sites in Lough Hyne.

Hurlbert (1971) noted that dominance and richness tend to increase with sample size. However, although this was the case for richness in the present study, dominance decreased significantly with sample (sponge) size. In a review, Birch (1981) concluded that both richness and dominance generally increase together, yet these parameters were significantly negatively correlated $(\mathrm{p}<0.001)$ in the present study. It should be noted that species richness should reach an asymptote with increasing sample size, and that this is not necessarily correlated with dominance. In a study of temporal succession in amphipods in Lough Hyne, richness was relatively constant after 4 mo of colonization but dominance was variable (Costello 1987). Furthermore, a study of the spatial distribution of amphipods on algae in Tasmania (Edgar 1983) found no relationship between richness and dominance. These 2 parameters are useful descriptors of assemblage structure but their interrelationship (if any) is uncertain. Dominance appears particularly vulnerable to both spatial and temporal variation.
Acknowledgements. We thank Dr D. Barry for suggesting and computing the Z-test, and for helpful discussion on statistical analyses. Dr P. G. Moore provided very helpful and constructive criticism. This study was assisted by a Department of Fisheries Studentship and a Department of Education maintenance award to M. J. C.

\section{LITERATURE CITED}

Bailey, N. T. J. (1981). Statistical methods in biology, 2nd edn. Hodder and Stoughton, London

Barnard, J. L. (1974). Evolutionary patterns in gammaridean Amphipoda. Crustaceana 27: 137-147

Biernbaum, C. K. (1981). Seasonal changes in the amphipod fauna of Microciona prolifera (Ellis \& Solander) (Porifera: Demospongia) and associated sponges in a shallow salt. marsh creek. Estuaries 4: 85-96

Birch, D. W. (1981). Dominance in marine ecosystems. Am Nat. 118: 262-274

Chevreux, E., Fage, L. (1925). Amphipodes. Faune Fr. 9: $1-488$

Connes, R. (1967). Réactions de défense de l'éponge Tethya lyncurium Lamarck, vis-à-vis des micro-organismes et de l'amphipode Leucothoe spinicarpa Abildg. Vie de Milieu A 18: 281-289

Connes, R., Paris, J., Sube, J. (1971). Réactions tissulaires de quelques démosponges vis-à-vis de leurs commensaux et parasites. Naturaliste can. 98: 923-935

Costello, M. J. (1987). Studies on amphipod Crustacea in Lough Hyne, Ireland: colonization of artificial substrata, population dynamics, distribution and taxonomy. Ph. D thesis, National Univ. of Ireland at Cork

Costello, M. J., Holmes, J. M. C., McGrath, D., Myers, A. A. (in press). A review and catalogue of Amphipoda (Crustacea) in Ireland. Ir. Fish. Invest. Ser. (in press)

Edgar, G. J. (1983). The ecology of south-east Tasmanian phytal animal communities. III. Patterns of species diversity. J. exp. mar. Biol. Ecol. 70: 181-203

Fage, L. (1928). Remarques sur le comportement du Tritaeta gibbosa (Bate), Crustace Amphipode, commensal des eponges. Bull. Soc. zool. Fr. 53: 285-291

Frith, D. W. (1976). Animals associated with sponges at North Hayling, Hampshire. Zool. J. Linn. Soc. 58: 353-362

Frith, D. W. (1977). A preliminary analysis of the association of amphipods Microdeutopus damnoniensis (Bate), $M$. anomalus (Rathke) and Corophium sextoni Crawford with sponges Halichondria panicea (Pallas) and Hymeniacidon perleve (Montagu). Crustaceana 32: 113-118

Gotto, R. V (1959). An ascidian 'Hotel' Ir. Nat. J. 13: 99

Hurlbert, S. H. (1971). The nonconcept of species diversity: a critique and altemative parameters. Ecology 52: 577-586

Kitching, J. A., Ebling, F. J. (1967). Ecological studies at Lough Ine. Adv. ecol. Res 4: 197-291

Kitching, J. A., Ebling, F. J., Gamble, J. C., Hoare, R., McLeod, A. Q. R., Norton, T A. (1976). The ecology of Lough Ine. XIX. Seasonal changes in the Western Trough. J. Anim. Ecol. 45: 731-758

Lincoln, R. J. (1979). British marine Amphipoda: Gammaridea. British Museum (Natural History), London

Lincoln, R. J., Boxshall, G. A., Clark, P. F. (1982). A dictionary of ecology, evolution and systematics. Cambridge University Press, Cambridge

Long, E. R. (1968). The associates of four species of marine sponges of Oregon and Washington. Pacif. Sci. 22: 347-351 
Myers, A. A., Costello M. J. (1984). The amphipod genus Aora in British and Irish waters. J. mar biol. Ass. U. K. 64: 279-283

Myers, A. A., McGrath, D. (1984). A revision of the North-East Atlantic species of Ericthonius (Crustacea: Amphipoda). J. mar biol. Ass. U. K. 64:379-400

Nagle, J.S. (1968). Distribution of the epibiota of macroepibenthic plants. Contr. mar. Sci. (Univ. Texas Mar Inst.) 13: 105-144

Ortiz, L. M. (1975). Algunos datos ecologicos de Leucothoe spinicarpa Abildgaard (Amphipoda, Gammaridea) en aguas Cubanas. Ciencias ser 8 Invest. Mar. no. 16: 1-12

Peattie, M. E., Hoare, R. (1981). The sublittoral ecology of the Menai Strait. II. The sponge Halichondria panicea (Pallas) and its associated fauna. Estuar coast. Shelf Sci. 13: 621-635

Renouf, L. P. W. (1931). Preliminary work of a new biological station (Lough Ine, Co. Cork, I. F. S.). J. Ecol. 19: 410-438

Ryland, J. S., Nelson-Smith, A. (1975). Littoral and benthic investigations on the west coast of Ireland. IV. Some shores in counties Clare and Galway. Proc. R. Ir. Acad. 75B: 245-266 Tattersall, W. M. (1913). Clare Island survey. Part 42. Amphipoda. Proc. R. Ir. Acad. 31B: 1-24

Vader, W. (1984). Notes on Norwegian marine Amphipoda. 8. Amphipods found in association with sponges and tunicates. Fauna norv. Ser. A 5: 16-21

Wilson, K. (1984). A bibliography of Lough Hyne (Ine) 1687-1982. J. Life Sci. R. Dublin Soc. 5: 1-11

This article was presented by Professor A. J. Southward; it was accepted for printing on September 9, 1987 